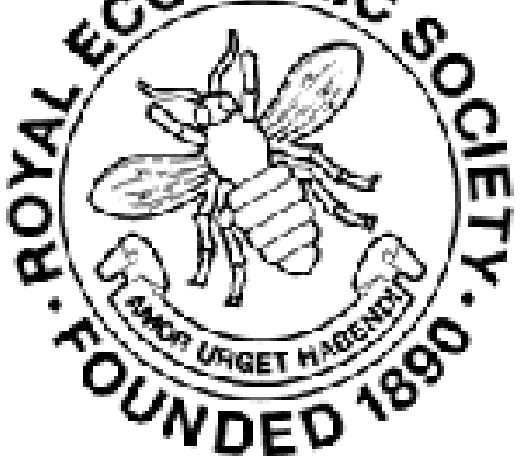

\title{
WILEY
}

\section{The Condition of India}

\section{Author(s): Cameron Morrison}

Source: The Economic Journal, Vol. 12, No. 48 (Dec., 1902), pp. 548-550

Published by: Wiley on behalf of the Royal Economic Society

Stable URL: http://www.jstor.org/stable/2957323

Accessed: 26-06-2016 20:22 UTC

Your use of the JSTOR archive indicates your acceptance of the Terms \& Conditions of Use, available at

http://about.jstor.org/terms

JSTOR is a not-for-profit service that helps scholars, researchers, and students discover, use, and build upon a wide range of content in a trusted digital archive. We use information technology and tools to increase productivity and facilitate new forms of scholarship. For more information about JSTOR, please contact support@jstor.org.

Royal Economic Society, Wiley are collaborating with JSTOR to digitize, preserve and extend access to The Economic Journal 


\section{The Condition of India}

Public attention in England has in recent years been increasingly directed to the magnitude and complexity of the financial and economic problems of our Indian administration. The position of that administration, representing the forces of a modern state economy thrust on the top of an ancient but little responsive civilisation, is absolutely without precedent in history. The Government of India in its aims, requirements and methods is abreast of any Western administration, while it legislates for, and draws the main resources for the execution of its vast schemes from a population which in its aims, requirements and methods, has not perceptibly advanced within historic times. There is no more instructive contrast than that between the crooked wooden plough of the Indian ryot and the vast system of law and government of which it is the mainstay. And the very system of land revenue by which the resourees of the country are made available is not the outcome of a long pondered scheme introduced from outside, but one inherited from the must decadent period of native rule, moulded and modified, indeed, by alien rulers to fit existing conditions, yet having as its chief and sole recommendation that it is the only system practically conceivable. Neither the Indian Government itself nor its defenders would claim for the financial system of the country any rounded completeness of logical consistency. In India where custom counts for more than wisdom, the expedient is invariably to be preferred to the logically simple, and financial policy consists in the careful readjustment of things as they have been from the beginning.

It is on their economic side, however, that Indian affairs have recently received most attention in Parliament and the press. In the first place, the country has been visited by a famine or rather a series of famines of unprecedented severity; in the second the public has had set before it, in the simple and effective language of the shop window, ${ }^{1}$ statements, if not arguments, seeking to prove that our policy in India, however brilliant in its superficial results, is gradually impoverishing the country. These statements, in proportion as they seek to catch the popular ear, must confine themselves to vague generalities, and for that very reason they are less susceptible of direct refutation. The case is different when a series of charges with chapter and verse are brought forward, bearing on different aspects of the land and revenue systems of India. In a recent series of letters to the Viceroy, ${ }^{2} \mathrm{Mr}$. R. C. Dutt, formerly of the India Civil, Service, and Lecturer on Indian History in the University of London, directly traverses the

${ }_{1} \mathrm{Mr}$. W. Digby's Prosperous British India, passim, necnon in tegmine libri.

2 Open Letters to Lord Curzon on Famines and Land Assessments in India, by Romesh C. Dutt, C.I.E. (London: Kegan Paul.) 
fiscal and land revenue systems of the country in their varied forms as carried out under the different local governments. To these charges the Government of India after consultation with the heads of Provinces has recently furnished an exhaustive reply. ${ }^{1}$ It is an open secret that) Lord Curzon has personally interested himself in the matter, and this is a guarantee that the rejoinder will not lack in fulness, cogency and directness. It is not our purpose here to go into the different questions threshed out in Lord Curzon's reply. To be understood, they presuppose a knowledge-often a technical knowledge - of Indian land tenures and their history. The protection against famine guaranteed by a permanent as opposed to a temporary settlement of the land; the fixing of an arithmetical ratio of the gross produce in determining the government demand in ryotwari estates, long term as opposed to short term settlements, and the various considerations that must be taken into, or left out of account, in determining the revenue for a new term of settlementthese are questions which concern the Indian, rather than the English student of economics. In them and their solution however are involved the broader questions of the justness or otherwise of the incidence of land revenue in India, the pressure of that revenue as affecting the ryot's standard of life and his power to resist the effects of famine, and, especially, the principles which guide the government in adjusting its demands on the cultivators. These questions are of the utmost interest to all, and it is this interest that gives its importance to the Resolution under review and rescues for it an important place in the somewhat scanty literature of a hitherto little considered department of economics. Besides, in the detailed replies (printed as an appendix) from the various provincial governments explanations other than those suggested by Mr. Dutt are given of the admitted poverty of large tracts of country. These have the advantage of being founded on experience gained by officers on the spot, and help the outsider to form a picture of Indian rural life and conditions not readily found elsewhere. One great complaint made by those acquainted with India against the ex parte charges brought against the administration of the country, is the entire absence in them of a reference to the life and customs of the people themselves. The ryot of India is a hard-working cultivator, but he is the very antithesis of the "economic man." Till his proverbial improvidence is exchanged for something better, it is idle to speak of administrative or fiscal changes from above as a panacea for India's woes.

The largest part of the executive efforts of the Indian Government has certainly hitherto been directed to the avoidance or mitigation of famines. Famines indeed really constitute the theoretical and practical

1 Resolution No. 1, 50-52 of the Government of India. Subject: Certain Recent Criticisms of the Land Revenue Policy of the Indian Government. 
economics of India. It is natural to expect therefore that the revenue system of India and its administration under Lord Curzon's Government should be subjected to criticism which turns mainly on this point. To quote the words of the Resolution itself, the main burden of that criticism is, that " the revenue taken by the Government of India in one form or other from the people is mainly responsible for famine, with the corollary that, were the assessments diminished, famine would be less frequent, or that at least when they do occur there would be less suffering." The Resolution argues that fact and theory are alike opposed to the contention that any connection exists between the rates of assessment and the ryot's indebtedness in ordinary years or his distress when the rains fail. This is indeed the kernel of the government's contention and the facts and arguments adduced in its support, together with the government's own explanation of the poverty of the ryot, throw a flood of light on the economic conditions of the agricultural population of India. India suffers primarily because in certain years no rain falls and crops and cattle die, and secondarily because her people have not yet learned the art of looking ahead. No better method for elucidating a great department of Indian economics could be imagined than this specific refutation of specific charges categorically put and answered. It goes without saying that when the government of Lord Curzon sets itself to write a detailed reply to a series of unofficial letters impugning its administration, it does not rest content with a mere logical or controversial victory over its opponents. Mr. Dutt has evidently let his indictment outrun his facts ; but, however bitter may be complaint of this indiscretion in the replies of the local governments, it is scarcely alluded to in the official Resolution itself. That Resolution is indeed intended to be much more than a reply to Mr. Dutt's letters. It is a reasoned statement of the general land revenue policy of the government of India in the past and an explanation of the principles by which it has been guided and by which it will be prepared to advance towards the amelioration of the condition of the agricultural classes of the country.

Cameron Morrison

\section{A Derbyshire Farmer's Budget, 1723-24}

John Bagshaw of Abney Grange was the largest and most prosperous farmer of that village. He was married in 1667, and had numerous children, two of whom, William (born 1669-70) and Peter (born 1681) grew up and had children of their own, and lived in the old farm along with their father. John Bagshaw was a man of some importance in the large parish of Hope, acting as churchwarden as 